\title{
Modulation of Butyrate Anticancer Activity by Solid Lipid Nanoparticle Delivery: An in Vitro Investigation on Human Breast Cancer and Leukemia Cell Lines
}

Federica Foglietta ${ }^{a^{*}}$, Loredana Serpe ${ }^{\mathrm{a}}$, Roberto Canaparo ${ }^{\mathrm{a}}$, Nicoletta Vivenza ${ }^{\mathrm{b}}$, Giovanna Riccio $^{\mathrm{b}}$, Erica Imbalzano $^{\mathrm{a}}$, Paolo Gasco $^{\mathrm{b}}$, Gian Paolo Zara ${ }^{\mathrm{a}}$

apipartimento di Scienza e Tecnologia del Farmaco, University of Torino, Torino, Italy. ' Nanovector srl, Environment Park, Torino, Italy

Received, February 19, 2014; Revised, May 17, 2014; Accepted, May 21, 2014; Published, May 25, 2014.

\begin{abstract}
Purpose. Histone modification has emerged as a promising approach to cancer therapy. The shortchain fatty acid, butyric acid, a histone deacetylase (HD) inhibitor, has shown anticancer activity. Butyrate transcriptional activation is indeed able to withdraw cancer cells from the cell cycle, leading to programmed cell death. Since butyrate's clinical use is hampered by unfavorable pharmacokinetic and pharmacodynamic properties, delivery systems, such as solid lipid nanoparticles (SLN), have been developed to overcome these constraints. Methods. In order to outline the influence of butyrate delivery on its anticancer activity, the effects of butyrate as a free (sodium butyrate, NB) or nanoparticle (cholesteryl butyrate solid lipid nanoparticles, CBSLN) formulation on the growth of different human cancer cell lines, such as the promyelocytic leukemia, HL-60, and the breast cancer, MCF-7 was investigated. A detailed investigation into the mechanism of the induced cytotoxicity was also carried out, with a special focus on the modulation of HD and cyclin-dependent kinase (CDK) mRNA gene expression by real time PCR analysis. Results. In HL-60 cells, CBSLN induced a higher and prolonged expression level of the butyrate target genes at lower concentrations than NB. This led to a significant decrease in cell proliferation, along with considerable apoptosis, cell cycle block in the G0/G1 phase, significant inhibition of total HD activity and overexpression of the p21 protein. Conversely, in MCF-7 cells, CBSLN did not enhance the level of expression of the butyrate target genes, leading to the same anticancer activity as that of NB. Conclusions. Solid lipid nanoparticles were able to improve butyrate anticancer activity in HL-60, but not in MCF-7 cells. This is consistent with difference in properties of the cells under study, such as expression of the TP53 tumor suppressor, or the transporter for short-chain fatty acids, SLC5A8.
\end{abstract}

This article is open to POST-PUBLICATION REVIEW. Registered readers (see "For Readers") may comment by clicking on ABSTRACT on the issue's contents page.

\section{INTRODUCTION}

Butyric acid is the main short-chain fatty acid (SCFA) produced by bacterial fermentation of dietary fiber in the colon. It is well known that butyrate plays an important role in the homeostasis of colonic mucosa by inducing pathways for cell maturation, as well as cell cycle arrest, differentiation and apoptosis (1). Butyrate-mediated regulation of apoptotic pathways also occurs in cancer cells, including myeloid leukemia and breast cancer cells, and is not limited to the gastrointestinal tract (2-4). Transcription is the primary target of butyrate, since it causes histone hyperacetylation through non-competitive and reversible inhibition of histone deacetylase (HD).
Butyrate enables DNA binding of several transcription factors, leading to higher genomic activity $(5,6)$. Apoptosis induced by histone deacetylase inhibitors (HDI) is generally associated with various disarrays of cell signaling pathways (7). Indeed, various studies have demonstrated the importance of epigenetic alteration, leading to gene silencing or abnormal expression as a cancer hallmark, and have proposed 'epigenetic' therapies capable of controlling transcription, as a promising approach in cancer therapeutics (8-10). The efficacy of HDI in cancer therapy may well stem from their restoration of silenced gene expression.

Corresponding Author: Federica Foglietta, Dipartimento di Scienza e Tecnologia del Farmaco, Università di Torino, Via Pietro Giuria 13, 10125 Torino, Italy; Email federica.foglietta@unito.it 
One such example is the fact that the powerful tumor suppressor p53 is the most commonly inactivated protein in human tumors (11). Its inactivation may be the result of TP53 gene alterations and approximately $50 \%$ of human cancers carry mutations in this gene (12).

It has now been well established that HDI treatment induces the expression of the cyclindependent kinase (CDK) inhibitor, p21. This plays a critical role in the regulation of cell cycle arrest and apoptosis, causing G1 arrest (13-16). HDIs have also been shown to induce p16 (CDKN2 or INK4) and p27, but they attenuate levels of cyclin A and cyclin $\mathrm{D}$, leading to decreased CDK4 and CDK2 activity (17). HDI treatment triggers both the intrinsic pathway and sensitizes tumor cells to the extrinsic death ligand-induced pathway of apoptosis $(17,18)$. HDIs also have non-histone substrates and can modulate transcription by directly acetylating/deacetylating transcription factors, as well as associated cofactors such as Sp1 transcription factors or proteins, including p53 (19). Butyric acid seems to be particularly selective in regulating gene expression, leading to transcriptional activation of certain genes, such as $C D K N 1 A$ coding p21 in a p53independent manner $(20,21)$. However, although the precise molecular mechanism involved in the cancer therapeutics of butyric acid has not yet been fully clarified, it does seem to be highly dependent on the cellular context.

The clinical use of butyrate as an anticancer agent is hampered by unfavorable pharmacokinetic and pharmacodynamic properties. These include its short half-life, which requires administration of continuous parenteral infusions to maintain therapeutic concentrations $(22,23)$. By extension, factors affecting intracellular accumulation of butyrate could potentially influence its availability to modulate gene expression and, hence, processes such as proliferation, differentiation and apoptosis (24). Although free diffusion of fatty acids may take place, it has very little physiological relevance in the uptake of butyrate. There is now a considerable body of evidence suggesting that SCFAs are predominantly taken up via a facilitated process involving a number of transport proteins.

The relatively recent characterization of a number of trans-membrane proteins has led to two well-defined routes of uptake, both monocarboxylate transport proteins: MCT1 also known as SLC16A1, a hydrogen coupled transporter, and SMCT1 (SLC5A8), a sodium-coupled transporter (25). Thus, varying levels of transporter expression may result in a varied cellular uptake of butyrate. In particular, SLC5A8 is the first plasma membrane transporter postulated to function as a tumor suppressor (26). Silencing of its expression by epigenetic mechanisms is an early event in the progression of colorectal cancer and re-expression of the gene in colon tumor cell lines induces apoptosis and prevents colony formation $(27,28)$.

The newly developing field of nanomedicine offers very promising applications for nanotechnology as a drug delivery platform. The aim of nanomedicine can be broadly defined as the comprehensive monitoring, control, construction, repair, defense and improvement of all human biological systems, working from the molecular level using engineered devices and nanostructures, ultimately to achieve medical benefits. Thanks to their small size, nanoparticulate drug delivery systems are encouraging goals in cancer therapy approaches. These include selective or targeted drug delivery, enhanced drug transport across biological barriers (leading to an increased bioavailability of the entrapped drug) or intracellular drug delivery, which minimizes systemic side effects and improves the solubility of poorly water-soluble drugs (29). Thus, cholesteryl butyrate solid lipid nanoparticles (CBSLN) have been put forward as a special delivery system to improve butyrate anticancer activity. This is because they are also a pro-drug, with the lipid matrix of solid lipid nanoparticles made up of cholesteryl butyrate i.e. the ester of cholesterol and butyric acid $(30,32)$. Previous studies have shown that CBSLN are able to prevent premature degradation of the incorporated butyrate and enhance cell membrane crossing (including the blood-brain barrier) (33), oral bioavailability and anticancer efficacy $(31,34-36)$. Moreover, CBSLN have shown very low systemic toxicity $(37,38)$ as their matrix contains physiological components and/or excipients of accepted status (FDA-approved constituents) $(39,40)$. Thus, CBSLN as a butyrate drug delivery system might be a valuable anticancer tool, since it improves several aspects of butyrate pharmacology. However, to date, there have been no reports on the effects of CBSLN on butyrate anticancer activity at molecular level.

Our aim was to investigate the anticancer activity of butyric acid as a lipid nanoparticle formulation, with special attention to mRNA gene expression modulation in different human cancer cell lines such as the promyelocytic leukemia, HL60 , and the breast cancer, MCF-7. 


\section{MATERIALS AND METHODS}

\section{Cholesteryl butyrate solid lipid nanoparticles}

CBSLN were prepared using the microemulsion method reported elsewhere $(30,31)$. Briefly, CBSLN were prepared from cholesteryl butyrate $(0.54 \mathrm{mmol})$ (Asia Talent Chemical, Shenzen, China) and Epikuron 200 (0.66 mmol) (Cargill, Milan, Italy). Epikuron 200 and cholesteryl butyrate were melted at $85^{\circ} \mathrm{C}$ and a warm solution of sodium glycocholate (0.39 mmol) (PCA, Basaluzzo, Italy) was added. 2phenylethanol (Sigma Aldrich, Milan, Italy) was used as a preservative $(0.25 \% \mathrm{w} / \mathrm{v}$ final dispersion). The microemulsion was then immediately dispersed in cold water (dispersion ratio 1:5 v/v) and washed by tangential flow filtration using a Vivaflow50 membrane (Sartorius Stedim Biotech GmbH, RC, Cut-off 100,000 Da) for purification of hydrophilic molecules (four washing steps were repeated by addition and removal of the same volume of water). The aqueous dispersion of CBSLN was then sterilized by $0.2 \mu \mathrm{m}$ filtration before use. Dispersion of CBSLN was characterized according to average diameter (Zave) and polydispersity index (PI) (Photon Correlation Spectroscopy (PCS), Malvern Zetasizer - Nano ZS - 176 Deg) and by determination of chemical composition (HPLC-UV analysis, Agilent 1260 and 1200). The zeta potential of the chol-but CBSLN dispersion after final sterilizing filtration was also characterized by laser Doppler velocimetry (LDV) (Malvern Zetasizer Nano ZS).

Fluo-cholesteryl butyrate SLN was prepared using the warm microemulsion method as for unlabeled CBSLN, by simply adding fluorescent dye in the lipid phase. Briefly, a warm microemulsion was prepared from cholesteryl butyrate (CBSLN $0.54 \mathrm{mmol}$ ), Epikuron 200 (PC) (0.66 mmol), 3,3'dioctadecyloxacarbocyanine perchlorate $(\mathrm{DiO}, \lambda$ ex: $484 \mathrm{~nm} / \lambda$ emiss: $501 \mathrm{~nm}$ ) (Biotium, Hayward USA) $(0.9 \mu \mathrm{mol})$, as the lipid phase and sodium glycocholate (NaGC, $0.39 \mathrm{mmol}$ ) (PCA, Basaluzzo, Italy) in the water phase; 2-phenylethanol ( $\mathrm{PhOH})$ (Sigma Aldrich, Milan, Italy) was added as a preservative $(0.25 \% \mathrm{w} / \mathrm{v}$ final dispersion $)$. DiOtagged CBSLN aqueous dispersion was washed and sterilized as for the previously reported unlabeled CBSLN.

Since the whole lipid matrix of CBSLN themselves acts as a prodrug of butyrate, solutions of sodium butyrate were freshly prepared in sterile water before each experiment and used as a drug reference.

\section{Cell culture and proliferation assay}

HL-60 and MCF-7 cell lines (ICLC, Interlabab Cell Line Collection, Genoa, Italy) were cultured in a growth medium (RPMI 1640 medium) supplemented with $2 \mathrm{mM}$ L-glutamine, $100 \mathrm{UI} / \mathrm{mL}$ penicillin, $100 \mu \mathrm{g} / \mathrm{mL}$ streptomycin and $10 \%(\mathrm{v} / \mathrm{v})$ heat-inactivated fetal calf serum (Sigma, St Louis, $\mathrm{MO}$, USA) in a humidified atmosphere of $5 \% \mathrm{CO}_{2}$ air at $37^{\circ} \mathrm{C}$.

The effect of butyrate, as NB or CBSLN, on HL60 and MCF-7 cell growth was evaluated by WST-1 cell proliferation assay (Roche Applied Science, Penzberg, Germany). $1 \times 10^{3}$ HL-60 and $2.5 \times 10^{3}$ MCF-7 cells were seeded in $100 \mu \mathrm{L}$ of growth medium in replicates $(\mathrm{n}=8)$ in a 96-well culture plate. After $72 \mathrm{~h}$ of cell growth, the medium was removed and the cells were incubated with the experimental medium containing different butyrate concentrations $(0.01,0.10,0.50$ and $1.00 \mathrm{mM})$. At 24 $\mathrm{h}$ and $48 \mathrm{~h}$, WST-1 reagent $(10 \mu \mathrm{L})$ was added and the plates were incubated at $37^{\circ} \mathrm{C}$ in $5 \% \mathrm{CO}_{2}$ for 2 $\mathrm{h}$. Well absorbance was measured at $450 \mathrm{~nm}$ and 620 $\mathrm{nm}$ (reference wavelength) in the Asys UV 340 microplate reader (Biochrom, Cambridge, UK). Cell proliferation data were expressed as a percentage of untreated cells.

\section{Flow cytometry}

Cell death was evaluated using the Dead Cell Apoptosis Kit with (allophycocyanin) APC-Annexin $\mathrm{V}$ and Sytox ${ }^{\circledR}$ Green (Life Technologies, Milan, Italy). Briefly, $5 \times 10^{5}$ HL-60 and MCF-7 cells were treated with butyrate (NB or CBSLN) $0.50 \mathrm{mM}$ and $1.00 \mathrm{mM}$, respectively. The cells were then washed twice with $1 \mathrm{x}$ annexin-binding buffer at $375 \mathrm{rcf}$ for 5 min and were stained with APC-Annexin V and Sytox ${ }^{\circledR}$ Green at 12, 24 and $48 \mathrm{~h}$. Samples were run on the flow cytometer at a $640 \mathrm{~nm}$ excitation to measure APC-Annexin V (FL4) and at $488 \mathrm{~nm}$ to measure Sytox ${ }^{\circledR}$ Green (FL1), respectively. Any cell debris with low FSC and SSC was excluded from the analyses. A total of 10,000 events were analyzed for APC-Annexin V (FL4) and Sytox ${ }^{\circledR}$ Green (FL1) staining to discriminate apoptotic (Annexin V positive) or late apoptotic/necrotic cells (Annexin V and Sytox ${ }^{\circledR}$ Green positive) from viable cells (Annexin V and Sytox ${ }^{\circledR}$ Green negative).

Cell cycle distribution was monitored by adding $2 \mu \mathrm{M}$ of Vybrant Dye Cycle Green (Invitrogen) live cell staining to $10^{6}$ cells for $30 \mathrm{~min}$ at $37^{\circ} \mathrm{C}$. Briefly, both the HL-60 and the MCF-7 cell cycle distributions were evaluated after the treatment with butyrate (NB or CBSLN) $0.50 \mathrm{mM}$ at $12 \mathrm{~h}$ and 1.00 
$\mathrm{mM}$ at $48 \mathrm{~h}$, respectively. The samples were run on the flow cytometer with a $488 \mathrm{~nm}$ excitation to measure the Vybrant Dye Cycle Green staining (FL2). Flow cytometry was carried out by a C6 flow cytometer (Accurri Cytometers, Milan, Italy) and the analysis was performed by a FCS Express 4 (BD Bioscience, Milan, Italy).

Cellular uptake studies of CBSLN were carried out by flow cytometry with 3,3'dioctadecyloxacarbocyanine perchlorate $(\mathrm{DiO})$ used as a fluorescence probe. The experiment was conducted on $1 \times 10^{5}$ cells in a six-well culture plate. Cells were incubated at $37{ }^{\circ} \mathrm{C}, 5 \% \mathrm{CO}_{2}$ in supplemented RPMI-1640 medium. Then, HL-60 and MCF-7 cells were treated with $1 \mathrm{~mL}$ of $0.50 \mathrm{mM}$ of DiO-tagged CBSLN in RPMI-1640 medium for 1, 5, 15, 30 and $60 \mathrm{~min}$. After each incubation period, the cells were washed three times with PBS, and resuspended in $300 \mu \mathrm{l}$ PBS and run on the flow cytometer with a $488 \mathrm{~nm}$ excitation to measure the DiO staining (FL1). Intracellular fluorescence was expressed as the integrated median fluorescence intensity (iMFI), which was the product of the frequency of DiO-tagged CBSLN positive cells and the median fluorescence intensity of the cells. Results were expressed as the iMFI ratio, i.e. the difference between the iMFI of treated and untreated cells and the iMFI of untreated cells (41).

\section{Fluorescence microscopy}

HL-60 and MCF-7 cellular uptake of 3,3'dioctadecyloxacarbocyanine perchlorate (DiO)tagged CBSLN was investigated by fluorescence microscopy. Briefly, the MCF-7 cells were left to attach for $24 \mathrm{~h}$ on glass coverslips in 24-well plate, 2 x $10^{5} \mathrm{HL}-60$ and MCF-7 cells were then incubated for $30 \mathrm{~min}$ with DiO-tagged CBSLN $0.50 \mathrm{mM}$. Five minutes before the programmed stop time, the cells were incubated with $1 \mu \mathrm{g} / \mathrm{mL}$ of 4',6-diamidino-2phenylindole (DAPI) for nuclear staining. Once the cells had been washed with PBS, the HL-60 cell suspensions and the MCF-7 on the coverslip were mounted onto a glass slide, observed under a DMI4000B fluorescence microscope (Leica, Wetzlar, Germany) and photographed. A total of 50 cells per slide were analyzed at 40x magnification in three separate areas, three times in three individual experiments.

\section{Real Time RT-PCR}

Depending on the effects obtained on cell growth, total RNA was isolated from the HL- 60 cells at 6 and
$12 \mathrm{~h}$ after NB or CBSLN $0.50 \mathrm{mM}$ treatment and from the MCF-7 cells at 24 and $48 \mathrm{~h}$ after NB or CBSLN $1.00 \mathrm{mM}$ treatment. Briefly, HL-60 and MCF-7 cells were collected in an RNA Cell Protection Reagent (Qiagen, Milan, Italy) and stored at $-80{ }^{\circ} \mathrm{C}$. Total RNA was then obtained using the RNeasy Plus Mini Kit (Qiagen). The total RNA concentration $(\mu \mathrm{g} / \mathrm{mL})$ was determined using the Qubit fluorometer (Invitrogen, Milan, Italy) and the Quant-IT RNA Assay Kit (Invitrogen) was used. Calibration was performed applying a two-point standard curve, according to the manufacturer's instructions. The integrity of the RNA samples was determined using the total RNA 6000 Nano Kit (Agilent Technologies, Milan, Italy) and the Agilent 2100 Bioanalyzer (Agilent Technologies).

Real-time RT-PCR analysis was carried out using $500 \mathrm{ng}$ of total RNA, which was reverse transcribed in a $20 \mu \mathrm{L}$ cDNA reaction volume using the QuantiTect Reverse Transcription Kit (Qiagen). In accordance with the manufacturer's instructions, $12.5 \mathrm{ng}$ of cDNA was used for each $10 \mu \mathrm{L}$ real-time RT-PCR reaction. Quantitative RT-PCR was performed using SsoFast EvaGreen (Bio-Rad, Milan, Italy) and the QuantiTect Primer Assay (Qiagen) was used as the gene-specific primer pair for the panel of genes studied (Table 1). The transcript of the reference glyceraldehyde-3phosphate dehydrogenase gene $(G A P D H)$ was used to normalize mRNA data and real-time PCR was performed using a MiniOpticon Real Time PCR system (Bio-Rad). The PCR protocol conditions were as follows: HotStarTaq DNA polymerase activation step at $95{ }^{\circ} \mathrm{C}$ for $30 \mathrm{~s}$, followed by 40 cycles at $95{ }^{\circ} \mathrm{C}$ for $5 \mathrm{~s}$ and $55^{\circ} \mathrm{C}$ for $10 \mathrm{~s}$. All runs were performed with at least three independent cDNA preparations per sample and all samples were run in duplicate. At least two non-template controls were included in all PCR runs. The quantification data analyses were performed using the Bio-Rad CFX Manager Software version 1.6 (Bio-Rad) according to the manufacturer's instructions. These analyses were performed in compliance with MIQE guidelines (Minimum Information for Publication of Quantitative Real-time PCR Experiments) (42).

\section{HD activity quantification}

Depending on the effects on cell growth, the HL-60 cells were collected at $12 \mathrm{~h}$ after NB or CBSLN 0.50 $\mathrm{mM}$ treatment and the MCF-7 cells at $48 \mathrm{~h}$ after NB or CBSLN $1.00 \mathrm{mM}$ treatment. 
Table 1. Gene description

\begin{tabular}{lll}
\hline Gene & Primers code & Description \\
\hline$A K T 1$ & QT00085379 & Protein kinase B \\
$A P A F 1$ & QT00092358 & Apoptotic peptidase activating factor 1 \\
$B A X$ & QT00062090 & Pro-apoptosis regulator \\
$B C L 2$ & QT00031192 & Anti-apoptosis regulator \\
$C D K 2$ & QT00005586 & Cyclin-dependent kinase 2 \\
$C D K 4$ & QT00016107 & Cyclin-dependent kinase 4 \\
$C D K N 1 A$ & QT00031192 & Cyclin-dependent kinase inhibitor 1A, p21 \\
$C D K N 2 A$ & QT00089964 & Cyclin-dependent kinase inhibitor 2A, p16 \\
GAPDH & QT01192646 & Glyceraldehyde-3-phosphate dehydrogenase \\
$H D A C 1$ & QT00015239 & Histone deacetylase 1 \\
$H D A C 2$ & QT00001890 & Histone deacetylase 2 \\
$H D A C 4$ & QT00005810 & Histone deacetylase 4 \\
$M A P 3 K 15$ & QT00041594 & Member of the mitogen-activated protein kinase \\
$N F K B 1$ & QT00063791 & Nuclear factor kappa-B DNA binding subunit \\
SLC5A8 & QT00199367 & Sodium-coupled monocarboxylate transporter 1 \\
SLC16A1 & QT00060676 & Solute carrier family 16 member 1 \\
$T P 53$ & QT00060235 & Tumor suppressor protein, p53 \\
\hline
\end{tabular}

In order to evaluate deacetylation by HD enzymes, nuclear extracts were prepared using the Nuclear Extract Kit (Active Motif, Rixensart, Belgium) to obtain the nuclear proteins, starting from $3 \times 10^{6}$ cells.

The protein concentration $(\mu \mathrm{g} / \mathrm{mL})$ was quantified using the Qubit fluorometer and the Quant-IT Protein Assay Kit. Calibration was performed applying a two-point standard curve, according to the manufacturer's instructions. We then used the colorimetric HD Assay Kit (Active Motif) according to the manufacturer's instructions. This colorimetric HD assay uses a short peptide substrate containing an acetylated lysine residue that can be deacetylated by class I, II and IV HD enzymes. Well absorbance was measured at $405 \mathrm{~nm}$ in the microplate reader Asys UV 340.

\section{p21 protein quantification}

HL-60 cells were collected at $12 \mathrm{~h}$ after NB or CBSLN $0.50 \mathrm{mM}$ treatment and the MCF-7 cells at $48 \mathrm{~h}$ after NB or CBSLN $1.00 \mathrm{mM}$ treatment. $1 \times 10^{6}$ cells were washed twice with PBS, collected in PBS and stored at $-80{ }^{\circ} \mathrm{C}$. The p21 in the cell lysates was analyzed using the p21 EIA kit (Enzo Life Sciences, Milan, Italy) according to the manufacturer's instructions. The protein concentration $(\mu \mathrm{g} / \mathrm{mL})$ was quantified using the Qubit fluorometer and the Quant-IT Protein Assay Kit. Calibration was performed applying a two-point standard curve, according to the manufacturer's instructions.

\section{STATISTICAL ANALYSIS}

Data are shown as the mean values \pm SD of three independent experiments. Statistical analyses were performed with GraphPad Prism 6.0 software (La Jolla, CA, USA) using the analysis of variance (twoway ANOVA). Bonferroni's test was used to calculate the threshold of significance. Statistical significance was set at $P<0.05$.

\section{RESULTS}

\section{Characterization of cholesteryl butyrate solid lipid nanoparticles}

The average diameter (Zave) and polydispersity index (PI) of CBSLN after $0.2 \mu \mathrm{m}$ filtration were $78.13 \mathrm{~nm}$ and 0.240 , respectively. The concentration of cholesteryl butyrate and consequently of butyrate, determined by reversed-phase HPLC after washing four times, were $38.6 \mathrm{mM}$ and $38.6 \mathrm{mM}$, respectively and, after $0.2 \mu \mathrm{m}$ filtration, $36 \mathrm{mM}$ and $36 \mathrm{mM}$, respectively.

\section{Effects of SLN butyrate delivery on cell proliferation}

CBSLN were observed to enhance butyrate antiproliferative activity in HL-60 cells but not in MCF-7 cells, as shown in Figure 1. In HL-60 cells, CBSLN determined a significant dose-dependent decrease in cell proliferation starting from $24 \mathrm{~h}$ of exposure, whereas NB induced only a slight reduction in cell proliferation at $48 \mathrm{~h}$ of exposure to 
the highest concentration tested $(1.00 \mathrm{mM})$. In MCF7 cells, CBSLN did not enhance the cytotoxic effects of butyrate, since it determined the same NB activity with a significant decrease in cell proliferation starting from $24 \mathrm{~h}$ of exposure to the highest concentration tested $(1.00 \mathrm{mM})$. CBSLN were able to increase butyrate activity in leukemic cells but not in breast cancer cells, as compared to free butyrate.

\section{Effects of SLN butyrate delivery on cell death}

On the basis of cell proliferation data (Figure 1), HL60 cell death was evaluated at 12, 24 and $48 \mathrm{~h}$ of exposure to $0.50 \mathrm{mM} \mathrm{NB}$ or CBSLN. At $0.50 \mathrm{mM}$, CBSLN induced a significant increase in the percentage of apoptotic and necrotic cells, which reached $50 \%$ and $30 \%$, respectively of the whole cell population at $12 \mathrm{~h}$. The increase in apoptotic and necrotic cell percentage was maintained for up to 48 $\mathrm{h}$ after treatment (Figure 2). Conversely, $0.50 \mathrm{mM}$ NB induced an increase in the apoptotic cell percentage which reached about $30 \%$ of the whole cell population only at $48 \mathrm{~h}$ (Figure 2). On the basis of cell proliferation data, MCF-7 cell death was evaluated at 24 and $48 \mathrm{~h}$ after $1.00 \mathrm{mM} \mathrm{NB}$ or CBSLN treatment. A slight increase in the apoptotic cell percentage was detectable only at $48 \mathrm{~h}$ with NB treatment, while the same formulation did not induce a significant increase in the percentage of necrotic cells (Figure 2). These data demonstrate that CBSLN were able to induce a significant increase in apoptotic and necrotic cell percentage, compared to free butyrate, at $12 \mathrm{~h}$, while CBSLN were not able to improve necrotic or apoptotic cell death in MCF-7 cells.
$24 \mathrm{~h}$

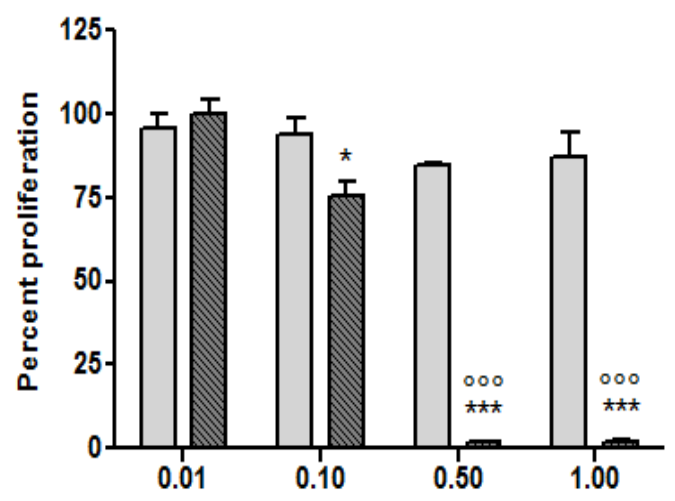

MCF-7

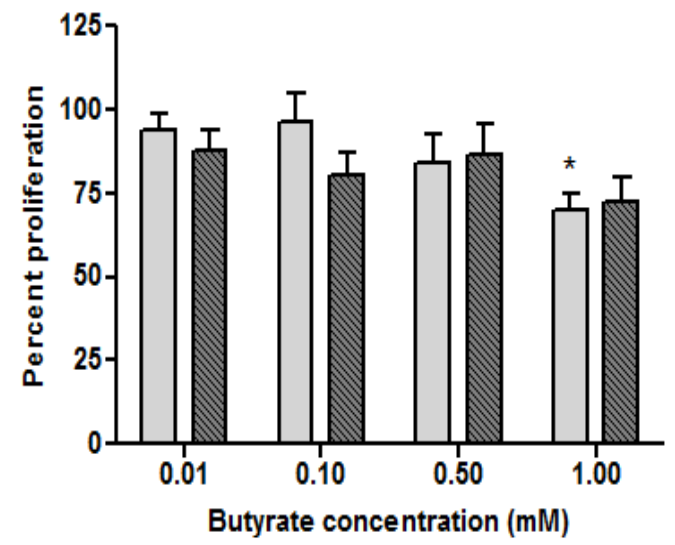

$48 \mathrm{~h}$
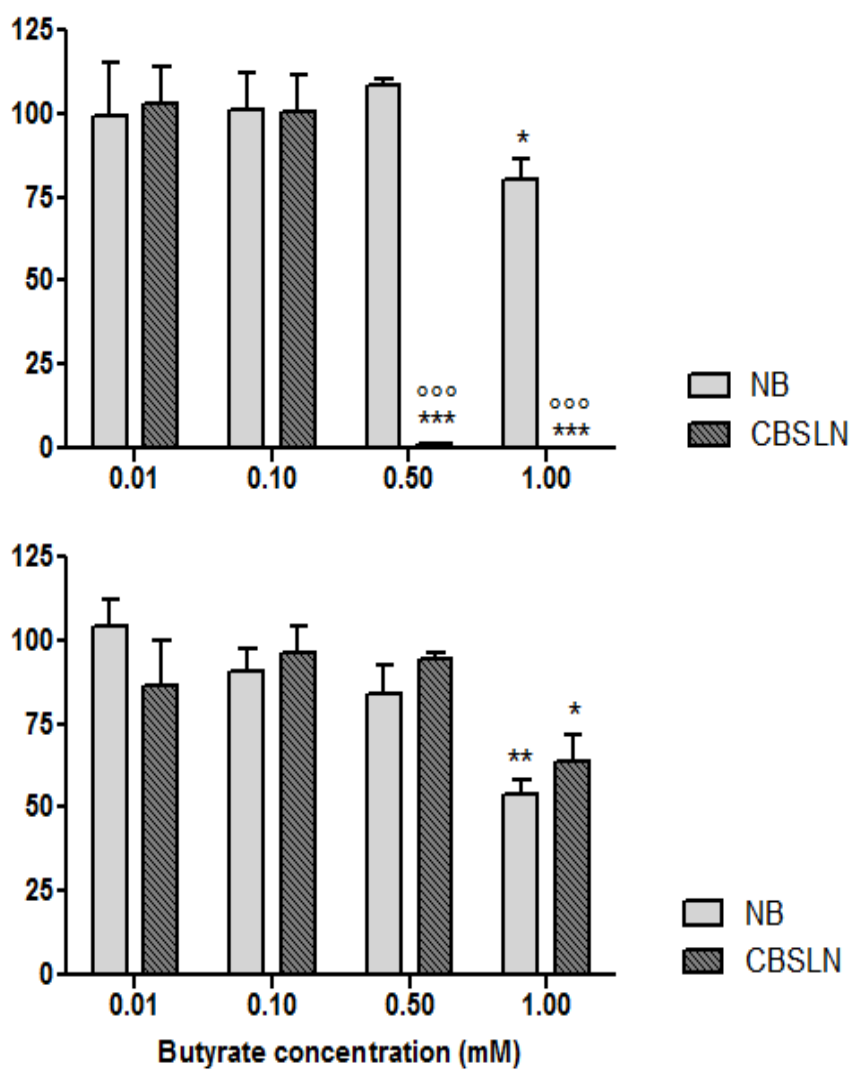

Figure 1. Effects of SLN butyrate delivery on cell proliferation. HL-60 and MCF-7 cell proliferation after exposure to increasing concentrations of butyrate as NB or CBSLN was evaluated at 24 and $48 \mathrm{~h}$ by WST-1 assay. Data are expressed as a percentage of control cells, i.e. untreated cells $(100 \%)$. ${ }^{*} P<0.05,{ }^{* *} P<0.01,{ }^{* * *} P<0.001$ statistical significance versus control cells; ${ }^{\circ 00} P<0.001$ statistical significance versus NB treated cells. 

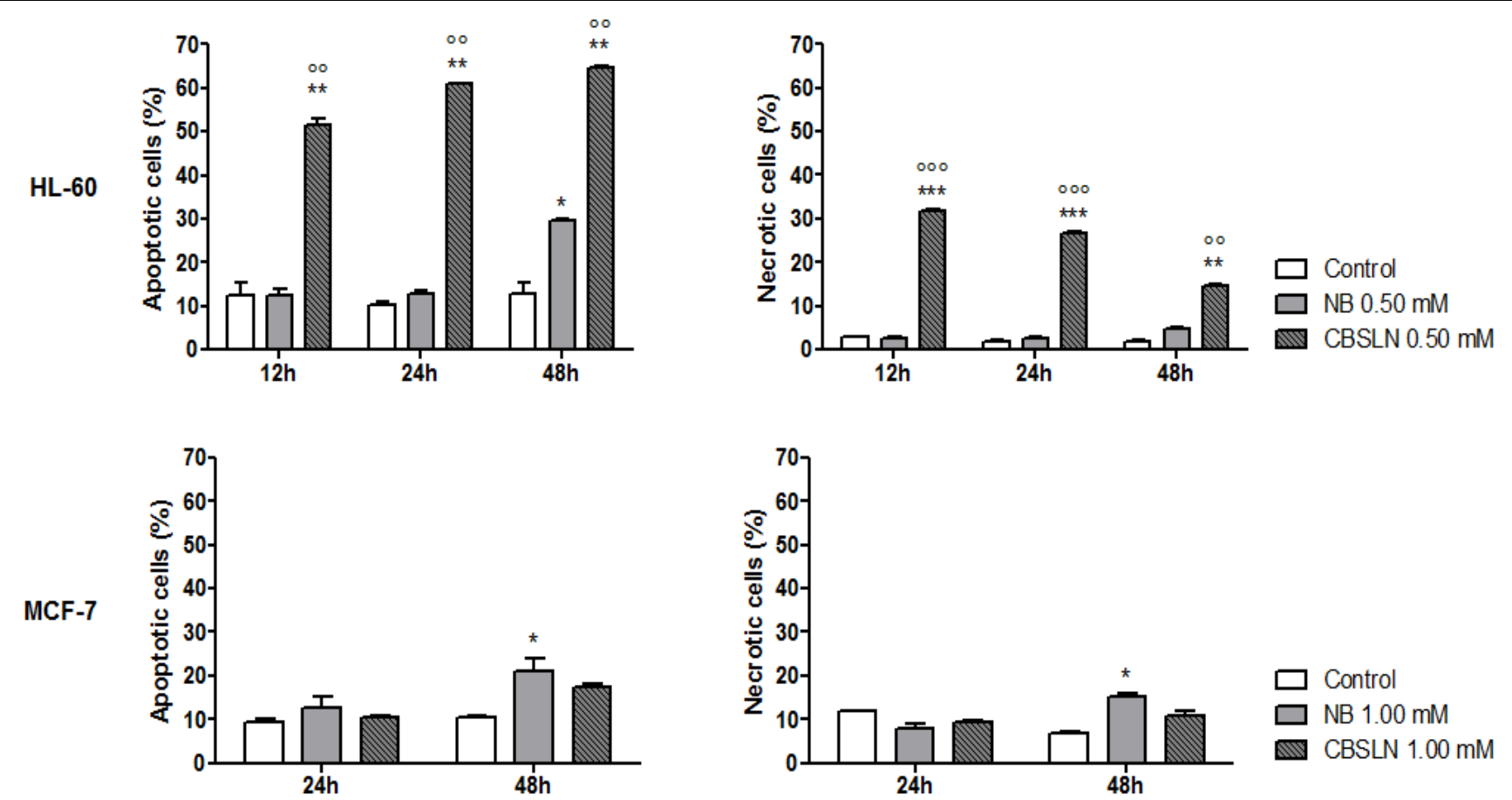

Figure 2. Effects of SLN butyrate delivery on cell death. Percentages of apoptotic and necrotic cells were obtained by flow cytometry with APC-Annexin V and Sytox Green for HL-60 at 12, 24 and $48 \mathrm{~h}$ exposure to $0.50 \mathrm{mM} \mathrm{NB}$ or CBSLN and for MCF-7 at 24 and $48 \mathrm{~h}$ exposure to $1.00 \mathrm{mM} \mathrm{NB}$ or CBSLN. $* P<0.05, * * P<0.01,{ }^{* * *} P<0.001$ statistical significance versus control cells; ${ }^{\circ} P<0.01,{ }^{\circ 00} P<0.001$ statistical significance versus NB treated cells.

\section{Effects of SLN butyrate delivery on cell cycle distribution}

The lowest butyrate concentrations able to influence cell proliferation, i.e. $0.50 \mathrm{mM}$ for HL-60 cells and $1.00 \mathrm{mM}$ for MCF-7 cells (Figure 1), were evaluated for their effects on cell cycle distribution. Owing to the severe decrease in HL-60 cell viability after 0.50 $\mathrm{mM}$ CBSLN treatment, cell cycle distribution was only evaluated at $12 \mathrm{~h}$ of incubation. A statistically significant difference in the percentage of HL-60 cells in each cell cycle phase was observed after exposure to $0.50 \mathrm{mM}$ CBSLN compared to both untreated and NB treated cells (Table 2). At 0.50 $\mathrm{mM}$, CBSLN showed a statistically significant increase in HL-60 cells in the G0/G1 phase and a reduction in the $\mathrm{S}$ and $\mathrm{G} 2 / \mathrm{M}$ phases, which was compatible with an arrest in the G0/G1 phase (Table 2). However, little difference was observed, in both $1.00 \mathrm{mM} \mathrm{NB}$ and CBSLN treated cells, in the proportion of MCF-7 cells in any cell cycle phase (Table 2). Thus, CBSLN were able to increase butyrate activity on the leukemic cell cycle, while the two butyrate formulations had similar effects on the breast cancer cell cycle.

\section{CBSLN cellular uptake}

Since differences in growth, death and cell cycle distribution were observed between HL-60 and MCF-7 cells exposed to the same CBSLN concentrations, their cellular uptake was investigated first by means of fluorescence microscopy. Both the HL-60 and MCF-7 cells seemed to have internalized the DiO-tagged CBSLN $0.50 \mathrm{mM}$ after $30 \mathrm{~min}$ of incubation in more than $80 \%$ of the whole cell population (Figure $3 \mathrm{a}$ and $\mathrm{b}$ ).

In order to explore the DiO-tagged CBSLN internalization, a flow cytometric analysis was performed. Specifically, leukemia cells were able to internalize DiO-tagged CBSLN $0.50 \mathrm{mM}$ with a high iMFI ratio $1 \mathrm{~min}$ after incubation, reaching maximum internalization at $30 \mathrm{~min}(P<0.001)$. The MCF-7 DiO-tagged CBSLN uptake was slower and almost constant during the time of incubation (Figure 3c). These data showed that the CBSLN internalization rate was higher and the kinetic uptake was faster in leukemia cells than in breast cancer cells. 
Table 2. Effects of SLN butyrate delivery on cell cycle distribution

\begin{tabular}{|c|c|c|c|c|c|c|c|c|}
\hline \multirow{2}{*}{ Butyrate } & \multirow{2}{*}{$\mathrm{mM}$} & \multicolumn{3}{|c|}{ HL-60 cells (\%) at $12 \mathrm{~h}$ exposure } & \multirow[t]{2}{*}{$\begin{array}{l}\mathrm{n} \\
\mathrm{N}\end{array}$} & \multicolumn{3}{|c|}{ MCF-7 cells (\%) at $48 \mathrm{~h}$ exposure } \\
\hline & & G0/G1 & $\mathrm{S}$ & $\mathrm{G} 2 / \mathrm{M}$ & & $\mathrm{G} 0 / \mathrm{G} 1$ & $\mathrm{~S}$ & $\overline{\mathrm{G} 2 / \mathrm{M}}$ \\
\hline Control & 0 & $31.5 \pm 2.5$ & $41.6 \pm 5.2$ & $26.8 \pm 3.1$ & 0 & $52.5 \pm 4.6$ & $37.9 \pm 3.2$ & $9.5 \pm 1.3$ \\
\hline NB & 0.50 & $34.5 \pm 4.1$ & $45.9 \pm 4.3$ & $19.4 \pm 2.7$ & 1.00 & $47.3 \pm 3.6$ & $32.4 \pm 4.5$ & $12.7 \pm 3.2$ \\
\hline CBSLN & 0.50 & $85.1 \pm 4.2 * * *$ & $10.8 \pm 2.1 * * *$ & $4.3 \pm 0.7^{* * *}$ & 1.00 & $51.7 \pm 6.4$ & $34.8 \pm 5.6$ & $10.7 \pm 2.7$ \\
\hline
\end{tabular}

\section{Effects of SLN butyrate delivery on gene expression}

Based on the cell proliferation data (Figure 1), HL60 RNA was extracted at 6 and $12 \mathrm{~h}$ after $0.50 \mathrm{mM}$ NB or CBSLN treatment and MCF-7 RNA was extracted at 24 and $48 \mathrm{~h}$ after $1.00 \mathrm{mM} \mathrm{NB}$ or CBSLN treatment. HL-60 samples $(n=18)$ had an RNA integrity number (RIN) of $10.00 \pm 0.00$ and MCF-7 samples $(n=18)$ had an RIN of $9.95 \pm 0.05$. The fold change in mRNA expression levels of genes involved in the butyrate mechanism of action, as compared to the control cells, i.e. untreated cells (expression level $=1$ ), is reported for HL-60 cells in Figure 4 and for MCF-7 cells in Figure 5.

We analyzed the gene expression profile of HL60 at 6 and $12 \mathrm{~h}$ after $0.50 \mathrm{mM} \mathrm{NB}$ (Figure $4 \mathrm{a}$ ) or CBSLN (Figure $4 \mathrm{~b}$ ) treatment. Of note is that the TP53 gene was not expressed in the HL-60 cell line (Figure 4a and b). No significant modifications was observed in the mRNA expression of the HD genes of class I, i.e. $H D A C 1$ and 2 (Figure $4 \mathrm{a}$ and b). Conversely, the HD gene of class II, HDAC4, was significantly over-expressed at $12 \mathrm{~h}$ after CBSLN treatment (Figure 4b).

As it is well known that butyrate is able to induce cell cycle arrest and apoptosis, we analyzed the expression levels of some genes involved in these pathways.

$C D K 4$, which regulates the cell cycle during G1/S transition, was slightly over-expressed at $6 \mathrm{~h}$ after NB (Figure $4 \mathrm{a}$ ) and $12 \mathrm{~h}$ after CBSLN treatment (Figure $4 \mathrm{~b}$ ). Furthermore, the mRNA expression level of $C D K N 2 A$, which codes for the CDK4 inhibitor p16, was increased at $6 \mathrm{~h}$ after NB treatment $(4.8 \pm 0.1$, Figure $4 \mathrm{a})$ and, to a greater extent, at $12 \mathrm{~h}$ after CBSLN treatment $(9.8 \pm 0.2$, Figure $4 \mathrm{~b})$. $C D K N 1 A$, which codes for the CDK inhibitor $\mathrm{p} 21-$ characterized by a specific sequence on its promoter region recognized by butyrate - was significantly over-expressed both at 6 and $12 \mathrm{~h}$ after NB (Figure $4 \mathrm{a})$ and CBSLN treatment (Figure $4 \mathrm{~b}$ ). The highest mRNA expression level of $C D K N 1 A$ was observed at $12 \mathrm{~h}$ after CBSLN treatment $(64.00 \pm 5.00$, Figure
$4 b)$. This expression profile was in line with the considerable G0/G1 block and apoptosis observed in HL-60 cells after $0.50 \mathrm{mM}$ CBSLN treatment (Table 2 and Figure 2). As treatment with HDI triggers cancer cells in both the extrinsic and intrinsic death ligand-induced pathways for apoptosis, we also analyzed genes such as AKT1 and APAFl. Specifically, it was observed that, $A K T 1$, which is involved in the transduction pathway of the tyrosinekinase receptor, was significantly over-expressed at $6 \mathrm{~h}$ after NB treatment (Figure $4 \mathrm{a}$ ) and at $12 \mathrm{~h}$ after CBSLN treatment (Figure 4b). APAF1, which mediates the cytochrome c-dependent autocatalytic activation of pro-caspase-9, was significantly overexpressed at $6 \mathrm{~h}$ after NB treatment (Figure 4a) and at $12 \mathrm{~h}$ after CBSLN treatment (Figure $4 \mathrm{~b}$ ). When the pro-apoptotic $B A X$ gene and the anti-apoptotic $B C L$ 2 gene were taken into consideration, no statistically significant differences were observed in the mRNA expression levels, either after NB (Figure 4a) or after CBSLN (Figure 4b) treatment. Furthermore, the expression of MAP $3 K 15$ and NFKB1 gene encoding transcriptional factors, which play an essential role in apoptotic cell death triggered by cellular stresses, was affected by neither butyrate, NB (Figure 4a) nor CBSLN (Figure 4b) treatment. The expression levels of two genes, SLC5A8 and SLC16A1 encoding butyrate transporters were also analyzed. There was no SLC5A8 expression in HL-60 cells (Figure 6a and b), whilst the mRNA expression level of SLC16A1 remained unaffected by butyrate both as NB (Figure 6a) and as CBSLN (Figure 6b).

We analyzed the MCF-7 gene expression profile at 24 and $48 \mathrm{~h}$ after $1.00 \mathrm{mM} \mathrm{NB}$ (Figure 5a) or CBSLN (Figure 5b) treatment. Noteworthy is the fact that the TP53 gene in the MCF-7 cell line was expressed and differentially modulated by NB and CBSLN at $24 \mathrm{~h}$, reaching control level at $48 \mathrm{~h}$ (Figure 5a and b). HDAC1, 2 and 4 were downexpressed at $24 \mathrm{~h}$ and over-expressed at $48 \mathrm{~h}$ by NB (Figure 5a). Conversely, these genes were overexpressed at $24 \mathrm{~h}$ and down-expressed at $48 \mathrm{~h}$ after CBSLN treatment (Figure 5b). 

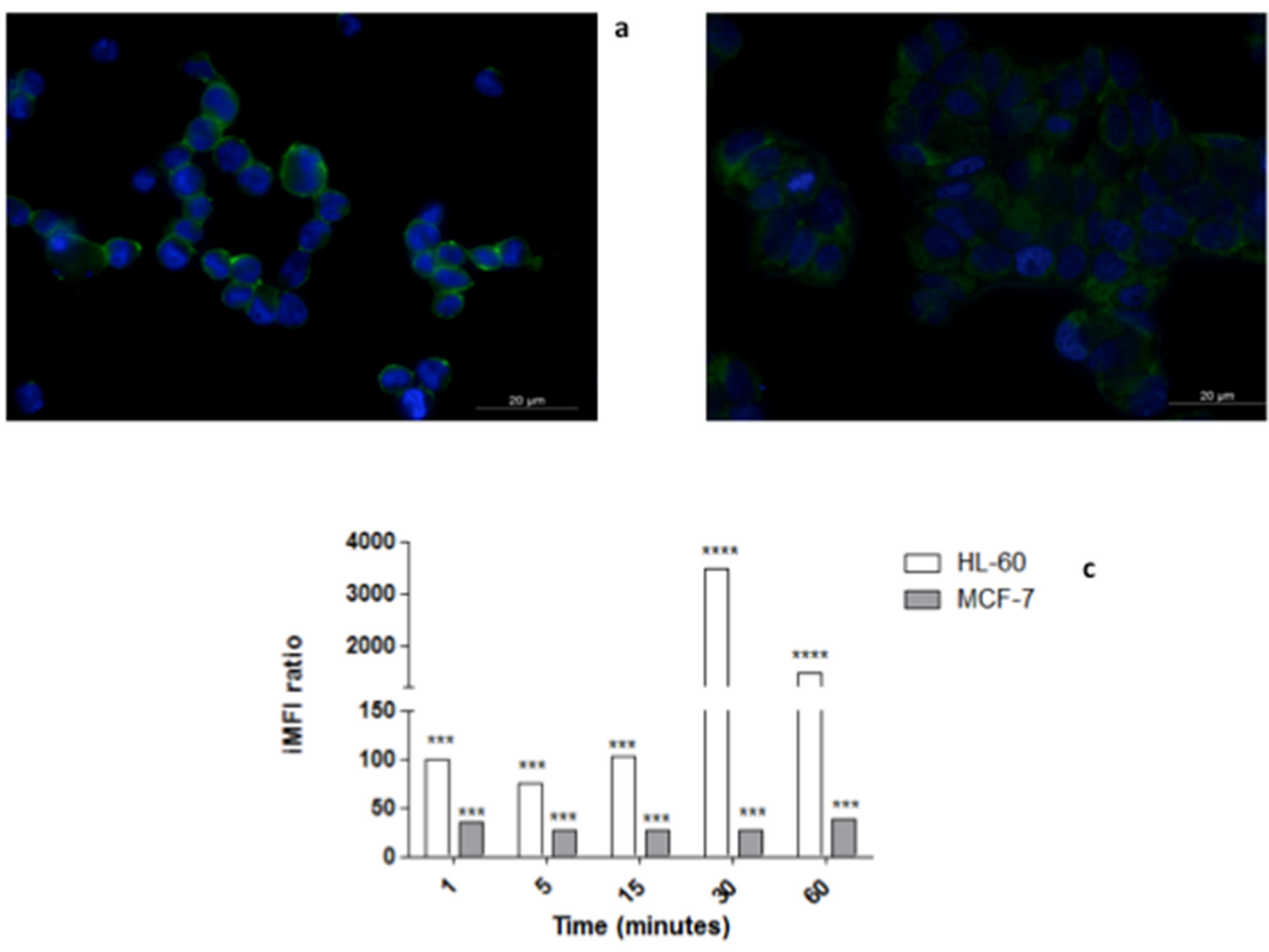

Figure 3. CBSLN cellular uptake. Figure a: Representative fluorescence image of HL-60 cells exposed to $0.50 \mathrm{mM} 3,3$ 'dioctadecyloxacarbocyanine perchlorate (DiO)-tagged cholesteryl butyrate solid lipid nanoparticles (CBSLN) (in green) for $30 \mathrm{~min}$; DAPI (in blue) was used as nuclear counterstain, at 63x magnification. Figure b: Representative fluorescence image of MCF-7 cells exposed to $0.50 \mathrm{mM}$ DiO-tagged CBSLN (in green) for $30 \mathrm{~min}$; DAPI (in blue) was used as nuclear counterstain, at $63 \mathrm{x}$ magnification. Figure c: Cellular uptake by flow cytometric analysis, cells was exposed to DiO-tagged CBSLN for different incubation time $(1,5,15,30,60 \mathrm{~min})$. Fluorescent signal was detected by a flow cytometer with a 488 $\mathrm{nm}$ excitation to measure the DiO staining (FL1) and expressed as integrated median fluorescence intensity (iMFI) ratio calculated as reported in Materials and Methods. $* * * P<0.001, * * * * P<0.0001$ statistical significance versus untreated cells.

mRNA expression levels of $C D K 2$ and $C D K 4$ had significantly decreased at $24 \mathrm{~h}$ after NB reaching control level at $48 \mathrm{~h}$ (Figure 5a). CBSLN modulated $C D K 2$ expression only at $24 \mathrm{~h}$ (Figure $5 \mathrm{~b}$ ). Although $C D K N 2 A$ was down-regulated by both $\mathrm{NB}$ and CBSLN at $48 \mathrm{~h}$, CBSLN treatment led to an upregulation at $24 \mathrm{~h}$ (Figure $5 \mathrm{a}$ and $\mathrm{b}$ ). CDKN1A was similarly modulated by NB and CBSLN reaching the same extent of over-expression at $48 \mathrm{~h}$ (Figure 5a and b). Moreover, $A K T 1$ was down- regulated at 48 $\mathrm{h}$ by NB and CBSLN treatment, as was NFKB1, whilst $B A X$ was slightly over-expressed (Figure 5a and $b$ ). Regarding the expression of the butyrate transporter genes, at $48 \mathrm{~h}$ we observed overexpression of $S L C 5 A 8$ after NB treatment and overexpression of SLC16A1 after CBSLN treatment (Figure 6c and d).

\section{Effects of SLN butyrate delivery on HD activity}

Data are expressed as the HD activity fold change compared to control cells, i.e., untreated cells. HD activity was $235.27 \pm 36.71 \mathrm{nmol} / \mathrm{min} / \mathrm{mg}$ in untreated HL-60 cells and $192.97 \pm 25.42$ $\mathrm{nmol} / \mathrm{min} / \mathrm{mg}$ in untreated MCF-7 cells. 
a

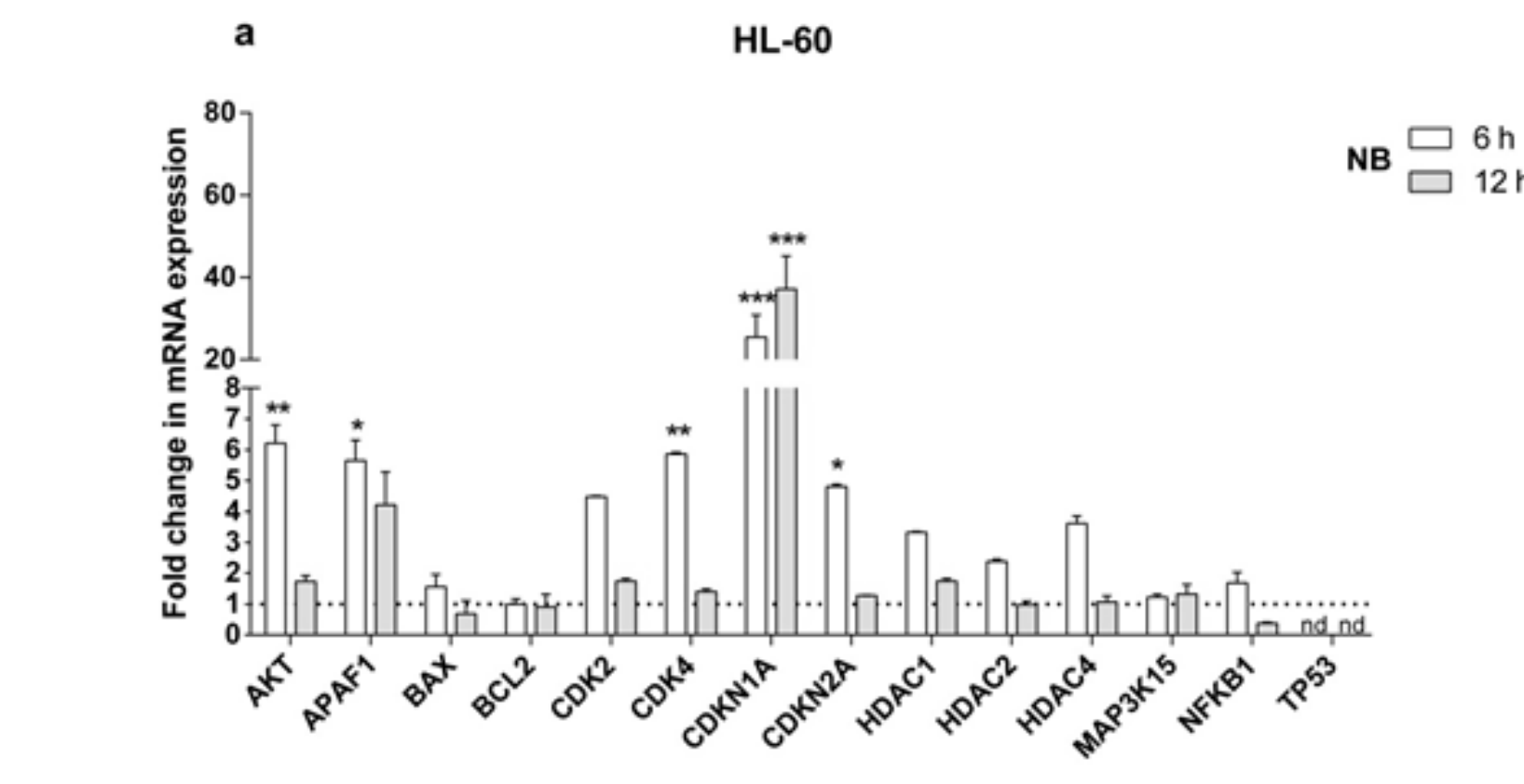

HL-60

b

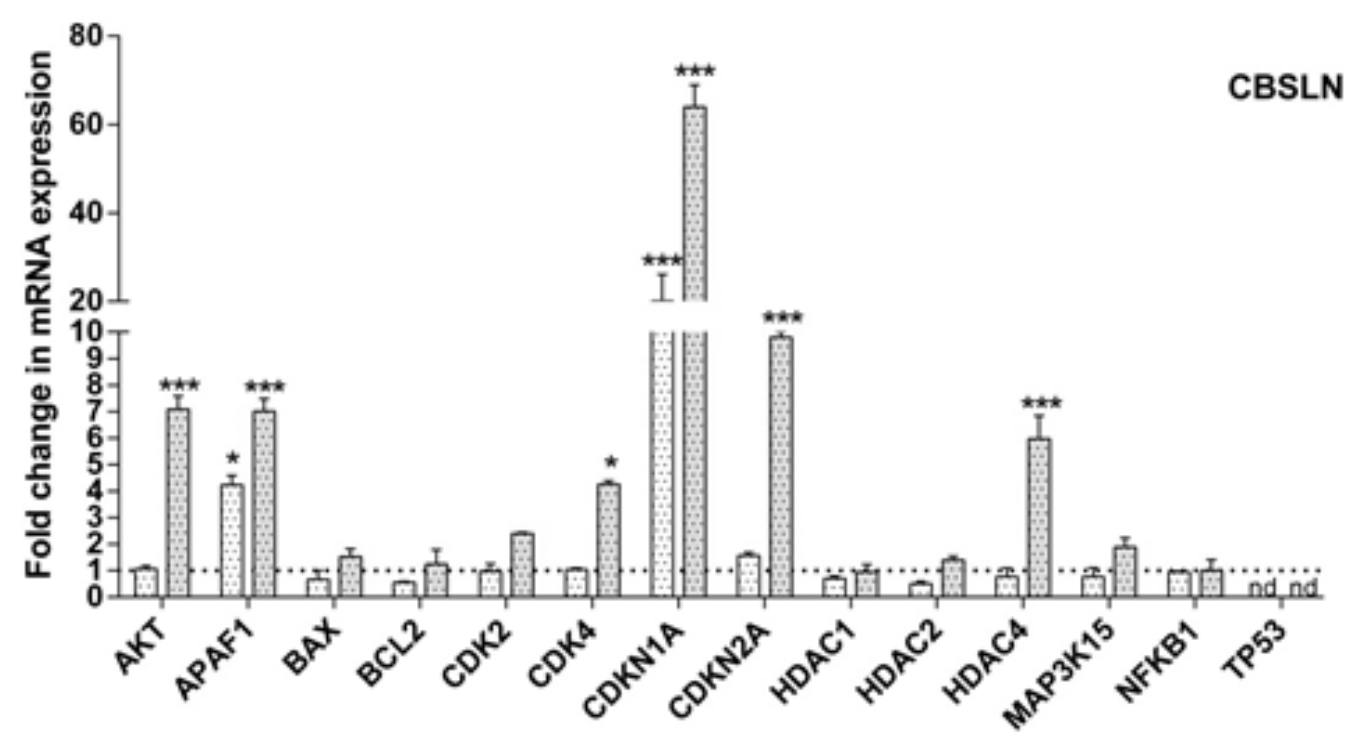

Figure 4. Effects of SLN butyrate delivery on HL-60 mRNA expression. mRNA gene expression was evaluated by real-time RT-PCR at 6 and $12 \mathrm{~h}$ from treatment with $0.50 \mathrm{mM}$ of butyrate as NB (a) or CBSLN (b). Values are relative to untreated cells represented as the dash line, i.e. a value of 1 ; nd: not detectable; $* P<0.05, * * P<0.01, * * * P<0.001$ statistical significance versus untreated cells.

There was a significant reduction in total HL-60 HD activity after $12 \mathrm{~h}$ of exposure to $0.50 \mathrm{mM} \mathrm{CBSLN}$, while NB had no effect (Figure 7a). Conversely, there was a slight decrease in the HD activity of MCF-7 nuclear extract samples after $48 \mathrm{~h}$ of exposure to $1.00 \mathrm{mM} \mathrm{NB}$, while CBSLN had no effect (Figure 7b).

These alterations in total HD activity are consistent with the HDAC4 mRNA over-expression observed in HL-60 cells at $12 \mathrm{~h}$ of exposure to 0.50
mM CBSLN (Figure 4b) and in MCF-7 cells at $48 \mathrm{~h}$ of exposure to $1.00 \mathrm{mM} \mathrm{NB}$ (Figure 5a), suggesting some kind of compensatory feedback (40).

Effects of SLN butyrate delivery on p21 protein expression

Data are expressed as the $\mathrm{p} 21$ protein expression fold change compared to control cells, i.e., untreated cells. The p21 protein was $2626.67 \pm 158.41 \mathrm{pg} / \mathrm{mL}$ in untreated HL-60 cells and 4760.00 \pm 310.03 
$\mathrm{pg} / \mathrm{mL}$ in untreated MCF-7 cells. A significant increase in $\mathrm{p} 21$ protein expression was observed in HL-60 cells after $12 \mathrm{~h}$ of exposure to $0.50 \mathrm{mM}$ CBSLN (Figure 8a), in line with the marked CDKN1A mRNA over-expression observed (Figure 4b). Conversely, there was no difference in the MCF-
7 p21 protein expression as compared to control cells after either NB, or CBSLN treatment (Figure 8b). This finding is in line with the slight increase in CDKN1A mRNA expression observed in MCF-7 cells after treatment with $1.00 \mathrm{mM} \mathrm{NB}$ or after CBSLN treatment (Figure 5a and b).
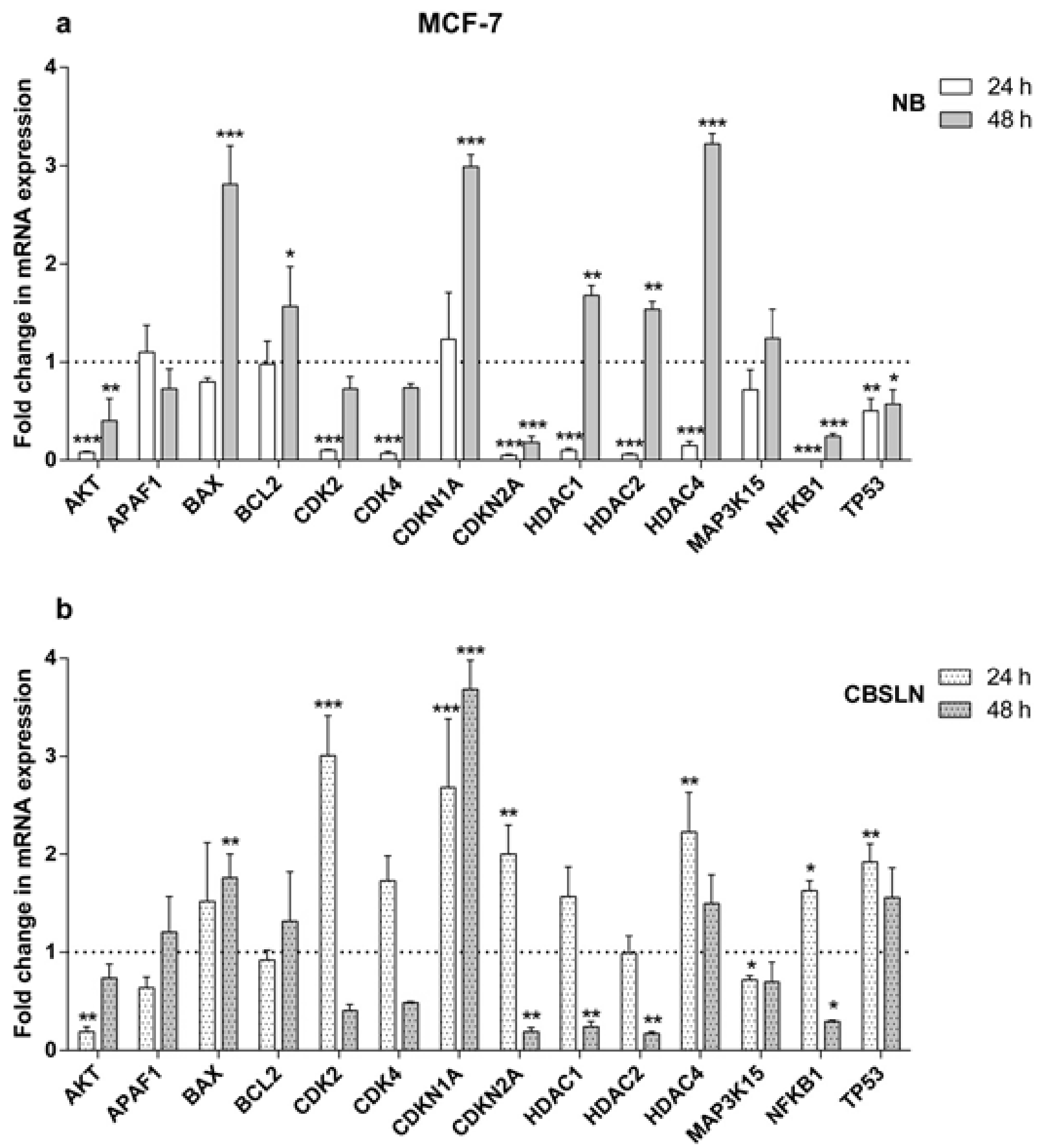

Figure 5. Effects of SLN butyrate delivery on MCF-7 mRNA expression. mRNA gene expression was evaluated by realtime RT-PCR at 24 and $48 \mathrm{~h}$ from the treatment with $1.00 \mathrm{mM}$ of butyrate as NB (a) or CBSLN (b). Values are relative to untreated cells represented as the dash line, i.e. a value of 1 ; nd: not detectable; ${ }^{*} P<0.05,{ }^{* *} P<0.01,{ }^{* * *} P<0.001$ statistical significance versus untreated cells. 

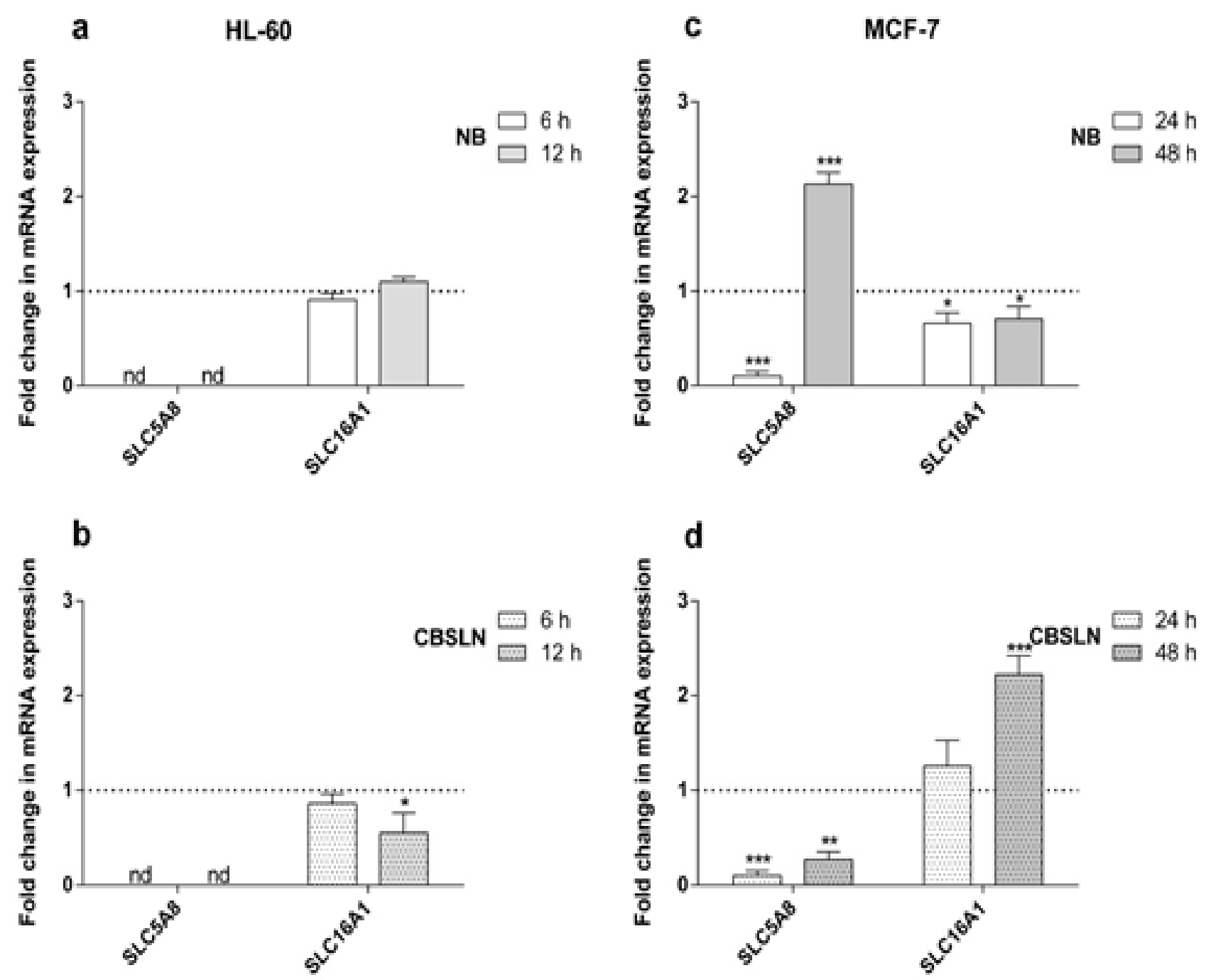

Figure 6. Effects of SLN butyrate delivery on mRNA expression of butyrate transporter genes. HL-60 mRNA gene expression was evaluated by real-time RT-PCR at 6 and $12 \mathrm{~h}$ from the treatment with $0.50 \mathrm{mM}$ of butyrate as NB (a) or CBSLN (b). MCF-7 mRNA gene expression was evaluated by real-time RT-PCR at 24 and $48 \mathrm{~h}$ from the treatment with 1.00 $\mathrm{mM}$ of butyrate as NB (c) or CBSLN (d). Values are relative to untreated cells represented as the dash line, i.e. a value of 1; nd: SLC5A8 gene expression not detectable in HL-60. $* P<0.05, * * P<0.01, * * * P<0.001$ statistical significance versus untreated cells.

\section{DISCUSSION}

Solid lipid nanoparticles are able to improve not only the pharmacokinetic, but also the pharmacodynamic properties of anti-cancer agents (39, 40, 43-45). Butyrate induces apoptosis and blocks in the G0/G1 phase in most cell lines at concentrations from 2 to 5 $\mathrm{mM}(14,46,47)$. Therefore, we investigated how solid lipid nanoparticles may influence the butyrate anticancer activity at a molecular level. CBSLNswere able to improve in vitro butyrate anticancer activity at lower concentrations in HL-60, but not in MCF-7 cells (Figure 1-2 and Table 2). These data are confirmed by the cellular uptake of fluorescent CBSLN, which was significantly higher in HL-60 than in MCF-7.

It is reasonable to suppose that the form of endocytosis involved in nanoparticle uptake could affect both intracellular localization and trafficking of the nanoparticles. To the best of our knowledge, differences in uptake extent and mechanism by hematological and epithelial cancer cell lines have not been reported to date. This is in spite of the fact that nanoparticles have been shown to exploit more than one pathway in their attempt to gain cellular entry (45). 

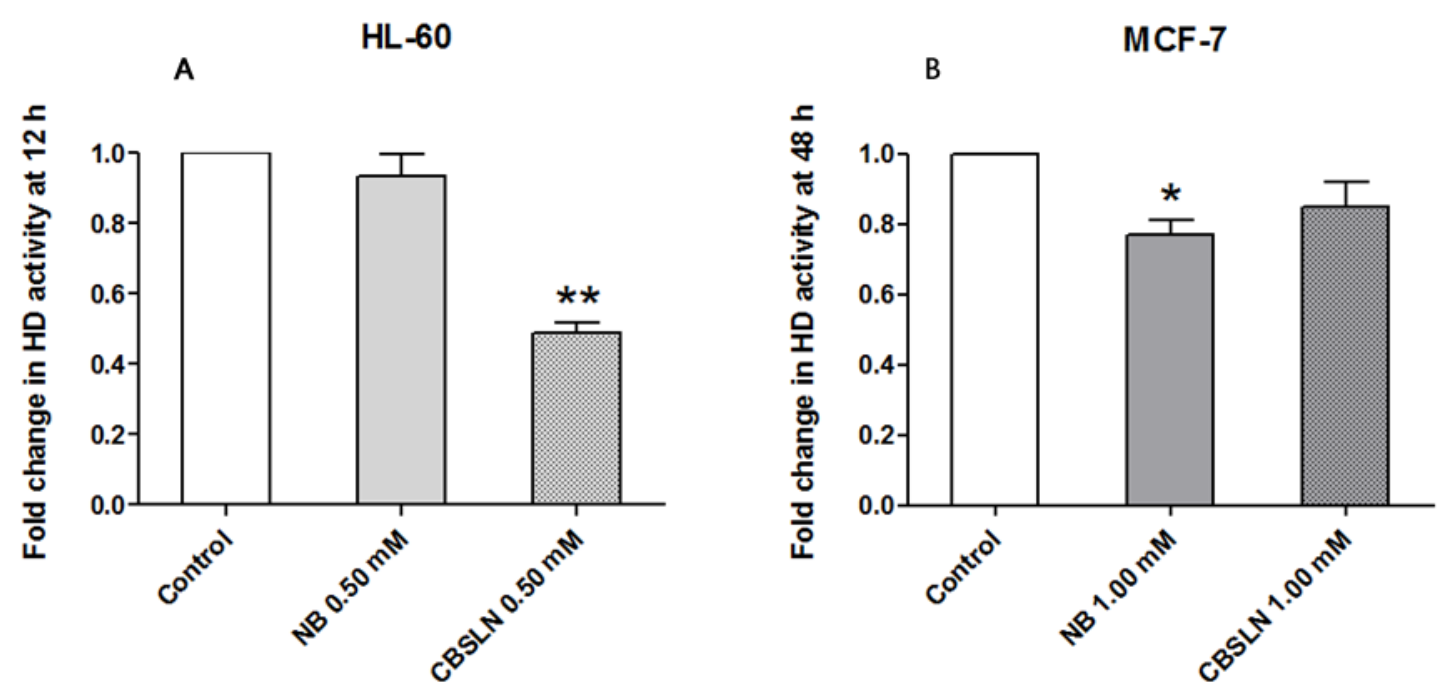

Figure 7. Effects of SLN butyrate delivery on HD activity. Data are presented as fold change compared to that of control cells, i.e. untreated cells. HD activity in untreated HL-60 cells was $235.27 \pm 36.71 \mathrm{nmol} / \mathrm{min} / \mathrm{mg}$ (a) and in untreated MCF-7 cells $192.97 \pm 25.42 \mathrm{nmol} / \mathrm{min} / \mathrm{mg}$ (b). $* P<0.05, * * P<0.01$ statistical significance versus control cells.
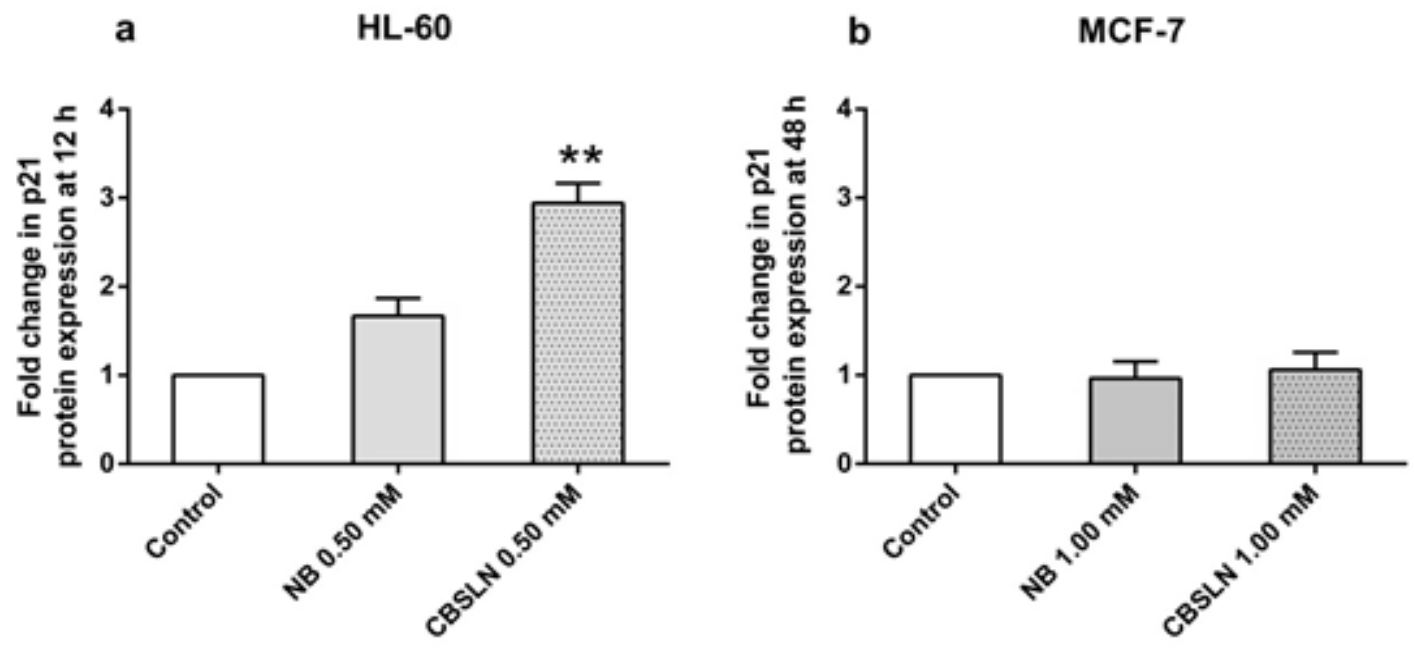

Figure 8. Effects of SLN butyrate delivery on p21 protein expression. Data are presented as fold change compared to that of control cells, i.e. untreated cells. p21 in untreated HL-60 cells was $2626.67 \pm 158.41 \mathrm{pg} / \mathrm{mL}$ (a) and in MCF-7 untreated cells $4760.00 \pm 310.03 \mathrm{pg} / \mathrm{mL}$ (b). $* * P<0.01$ statistical significance versus control cells.

We hypothesized that the different anticancer efficacy of butyrate as CBSLN between HL-60 and MCF-7 cells may be due to differences in the apoptotic mechanisms involved and/or butyrate cellular transport between the two cell lines. First of all, we investigated butyrate activity as NB or CBSLN in each cell line.
In HL-60 cells, NB and CBSLN had different effects on the expression of genes involved in the butyrate mechanism. In particular, NB determined a lesser and earlier mRNA over-expression (Figure 4a) than CBSLN, which determined a marked overexpression at $12 \mathrm{~h}$ (Figure $4 \mathrm{~b}$ ). A possible explanation for this might well be the different cell 
uptake kinetics as NB or CBSLN, which, in turn, leads to a different transcriptional activity. Of note is that CBSLN induced an up-regulation of HDAC4 mRNA expression at $12 \mathrm{~h}$ in HL-60 cells (Figure 4b) and, at the same time, a significant decrease in total HD activity (Figure 7a).

These data are in line with the hypothesis of a HDI-triggered self-regulatory loop due to a compensatory feedback pathway of HD transcription after inhibition of its enzymatic activity (40). Moreover HL-60 cells are TP53 null cells and CBSLN induced a marked CDKN1A mRNA overexpression both at 6 and $12 \mathrm{~h}$ (Figure 4b) and a significant increase in $\mathrm{p} 21$ protein expression at $12 \mathrm{~h}$ (Figure 8a). In keeping with these data, various studies have reported that butyrate dramatically increases p21 expression in cancer cells, such as osteosarcoma, colon carcinoma, glioma and lung cancer (15). The binding of p21 to the cyclin/cyclindependent kinase (CDK) complex is reported to be the main mechanism of butyrate induced inhibition of proliferation, which plays an essential role in G0/G1 arrest. Effectively, it has been reported that p21 forms complexes with cyclin D and CDK 4 or 6 as well as with cyclin E and CDK 2, thus reducing CDK activities and leading to inhibition of G1-S transition (48). Moreover, CDKN1A coding for $\mathrm{p} 21$ has a specific sequence in its promoter region, which is recognized by the $\mathrm{Sp} 1 / \mathrm{Sp} 3$ transcription factors. Indeed, some authors have reported that the butyrate up-regulation of p21 can be explained by selective butyrate regulation of the $\mathrm{Sp}$ transcriptional activators, leading to a common mechanism for cell cycle arrest and apoptosis $(19,49)$.

Our data are in line with several literature reports linking the rise in $\mathrm{p} 21$ levels to a histone-direct effect of HDI $(14,22,50)$. Butyrate may also modulate other CDK inhibitors, such as p16 coding by $C D K N 2 A$, whose transcription is up-regulated by CBSLN in HL-60 cells (Figure $4 b$ ). This result is in line with Siavoshian's work, where the author reported that treatment of HT-29 with butyrate strongly induces cyclin D and p21 expression, but does not influence $C D K 4, C D K 6$ and $P 16$ expression (51). The butyrate transporter SLC5A8 was not expressed in HL-60 cells (Figure 6a), whereas the SLC16A1 transporter was expressed and modulated only by CBSLN (Figure 6b). CBSLN was then able to enhance the butyrate inhibition of HL-60 cell proliferation through a p53 independent pathway as a result of HD inhibition, resulting in marked CDKN1A mRNA over-expression and an increase in p21. Therefore, the different butyrate activity in HL-
60 cells as CBSLN or NB may be related to butyrate intracellular trafficking improved by SLN, since the active butyrate transporter SLC5A8 was not expressed.

Figure 5 shows the expression profile of genes involved in the butyrate mechanism of action in MCF-7 cells exposed to NB or CBSLN. Noteworthy is the fact that NB and CBSLN determined upregulation of the same genes at different time points. There was a general up-regulation trend in the same genes at $48 \mathrm{~h}$ for NB and at $24 \mathrm{~h}$ for CBSLN. Conversely, NB down-regulated TP53 transcription, whilst CBSLN up-regulated it. NB led to a significant up-regulation of the mRNA expression of $H D A C 4$ at $48 \mathrm{~h}$. These data are in line with the slight NB-induced decrease in total HD activity observed in the MCF-7 cells (Figure 7b). Some authors have reported that butyrate inhibits cell proliferation in p53 wild type cancer cells, such as MCF-7, through the p53 pathway. Indeed p53 acetylation precedes the induction of $B A X$, suggesting that p53 mediates NB-induced apoptosis (52-54). Noteworthy was the fact that neither as NB nor as CBSLN was butyrate able to up-regulate $C D K N 1 A$ mRNA expression in MCF-7 cells to such an extent as to induce an increase in p21 protein expression (Figure 8b). Moreover, NB induced a notable up-regulation of the mRNA expression of $B A X$ at $48 \mathrm{~h} . C D K 2$ and $C D K 4$ were significantly down-regulated by NB at $24 \mathrm{~h}$, reaching control level at $48 \mathrm{~h}$. This result is in line with the down-regulation of $C D K 4$ gene expression in the human non-small lung carcinoma cell line H460 treated with NB (47). Butyrate as NB or CBSLN induced a different modulation of the butyrate transporters SLC5A8 and SLC16A1 in MCF-7 cells (Figure 6c and d), i.e., NB-induced SLC5A8 over-expression at $48 \mathrm{~h}$, while CBSLN induced SLC16A1 over-expression at the same time point. Hence, the same butyrate activity as CBSLN or NB in MCF-7 cells may be related to the upregulation of the butyrate active transporters genes SLC5A8 and SLC16A1.

Since the primary target of butyrate may be transcription in both cell lines, CBSLN determined an improved treatment response, as compared to NB, only in HL-60 cells due to the cellular survival/death network. Such findings were also supported by other studies, where low levels of p53 expression are linked to a resistance to HDI (55). Although butyrate's ability to stimulate apoptosis in some adenocarcinoma cells has been well documented, sensitivity to butyrate-induced apoptosis is quite variable and some authors have reported that the 
magnitude of $\mathrm{p} 21$ protein induction in colon cancer cell lines was smaller in the p53 wild-type cell lines than in the p53 mutant cell lines (20). Indeed, using a retroviral delivery system, an overexpression of p21 in mammary tumor cells led to increased apoptosis (55). Furthermore, some data suggest that histone hyperacetylation is partly responsible for the induction of p21 on colon cancer cell lines, because both butyrate and the specific inhibitor of histone deacetylase as trichostatin A resulted in a similar induction of p21 (56). Moreover, as the ability of butyrate to exert its effects depends on its intracellular concentration, solid lipid nanoparticles may improve butyrate concentration, especially in those cells where active butyrate transporters, such as SLC5A8, are not expressed (e.g., HL-60 cells).

Compared to the hydrogen-coupled transporter SLC16A1, SLC5A8 appears to have an extremely high affinity for butyrate at normal concentrations (25). Moreover, this evidence, along with the fact that SLC5A8 is coupled to a $\mathrm{Na}^{+}$concentration gradient, means there is a far greater "push" of butyrate into the cells than with SLC16A1. Indeed, as SLC16A1 relies on an $\mathrm{H}^{+}$gradient and as the magnitude of this gradient across the apical membrane is negligible, there is a smaller driving force pushing butyrate across (27). Therefore, the same effects determined by NB and CBSLN in MCF-7 cells may be due to an NB-induced overexpression of $S L C 5 A 8$, which may lead to improved butyrate cellular uptake. Moreover, SLC5A8 butyrate-mediated inhibition of $\mathrm{HD}$ has been reported as the underlying mechanism of the tumorsuppressive function of SLC5A8 (25).

\section{CONCLUSION}

Delivery of butyrate by solid lipid nanoparticles was able to considerably improve butyrate transcriptional activation in HL-60 cells only, leading to enhanced anticancer activity. According to the mRNA gene expression profile, we hypothesize that the different modulation of gene transcription was due to cell properties such as the expression of SLC5A8 with different patterns of butyrate internalization as a consequence. Indeed, HL-60 does not express SLC5A8 (Figure 6a, b), however it was expressed in MCF-7 cells (Figure 6c, d). Therefore, on the basis of these findings, pharmacological enhancement of butyrate transport as solid lipid nanoparticles, according to the specific cancer cell properties, may well represent a useful therapeutic tool in future cancer treatment protocols.

\section{ACKNOWLEDGEMENTS}

This work has been supported by the Converging Technologies Research Grant (Nano-IGT Project) from Regione Piemonte, Italy. The authors thank Barbara Wade for her advice on the use of the English language.

\section{REFERENCES}

1. Pajak B, Orzechowski A, Gajkowska B. Molecular basis of sodium butyrate-dependent proapoptotic activity in cancer cells. Adv Med Sci. 2007;52:83-8.

2. Goncalves P, Araujo JR, Martel F. Characterization of butyrate uptake by nontransformed intestinal epithelial cell lines. J Membr Biol. 2011;240:35-46.

3. Rahmani M, Dai Y, Grant S. The histone deacetylase inhibitor sodium butyrate interacts synergistically with phorbol myristate acetate (PMA) to induce mitochondrial damage and apoptosis in human myeloid leukemia cells through a tumor necrosis factor-alpha-mediated process. Exp Cell Res. 2002;277:31-47.

4. Chopin V, Slomianny C, Hondermarck H, Le Bourhis $\mathrm{X}$. Synergistic induction of apoptosis in breast cancer cells by cotreatment with butyrate and TNF-alpha, TRAIL, or anti-Fas agonist antibody involves enhancement of death receptors' signaling and requires P21(waf1). Exp Cell Res. 2004;298:560-73.

5. Riggs MG, Whittaker RG, Neumann JR, Ingram VM. n-Butyrate causes histone modification in HeLa and Friend erythroleukaemia cells. Nature. 1977;268:462-4.

6. Sealy L, Chalkley R. The effect of sodium butyrate on histone modification. Cell. 1978;14:115-21.

7. Chen J, Ghazawi FM, Bakkar W, Li Q. Valproic acid and butyrate induce apoptosis in human cancer cells through inhibition of gene expression of Akt/protein kinase B. Mol Cancer. 2006;5:71.

8. Jones PA, Baylin SB. The fundamental role of epigenetic events in cancer. Nat Rev Genet. 2002;3:415-28.

9. Bhalla KN. Epigenetic and chromatin modifiers as targeted therapy of hematologic malignancies. J Clin Oncol. 2005;23:3971-93.

10. Minucci S, Pelicci PG. Histone deacetylase inhibitors and the promise of epigenetic (and more) treatments for cancer. Nat Rev Cancer. 2006;6:38-51.

11. Vousden KH, Lane DP. p53 in health and disease. Nat Rev Mol Cell Biol. 2007;8:275-83.

12. Brown CJ, Lain S, Verma CS, Fersht AR, Lane DP. Awakening guardian angels: drugging the p53 pathway. Nat Rev Cancer. 2009;9:862-73.

13. Lavelle D, Chen YH, Hankewych M, DeSimone J. Histone deacetylase inhibitors increase p21(WAF1) and induce apoptosis of human myeloma cell lines 
independent of decreased IL-6 receptor expression. Am J Hematol. 2001;68:170-8.

14. Blagosklonny MV, Robey R, Sackett DL, Du L, Traganos F, Darzynkiewicz Z, et al. Histone deacetylase inhibitors all induce $\mathrm{p} 21$ but differentially cause tubulin acetylation, mitotic arrest, and cytotoxicity. Mol Cancer Ther. 2002;1:937-41.

15. Chopin V, Toillon RA, Jouy N, Le Bourhis X. $\mathrm{P} 21$ (WAF1/CIP1) is dispensable for G1 arrest, but indispensable for apoptosis induced by sodium butyrate in MCF-7 breast cancer cells. Oncogene. 2004;23:21-9.

16. Tonelli R, Sartini R, Fronza R, Freccero F, Franzoni $\mathrm{M}$, Dongiovanni D, et al. G1 cell-cycle arrest and apoptosis by histone deacetylase inhibition in MLLAF9 acute myeloid leukemia cells is p21 dependent and MLL-AF9 independent. Leukemia. 2006;20:1307-10.

17. Lindemann RK, Gabrielli B, Johnstone RW. Histonedeacetylase inhibitors for the treatment of cancer. Cell Cycle. 2004;3:779-88.

18. Guo F, Sigua C, Tao J, Bali P, George P, Li Y, et al. Cotreatment with histone deacetylase inhibitor LAQ824 enhances Apo-2L/tumor necrosis factorrelated apoptosis inducing ligand-induced death inducing signaling complex activity and apoptosis of human acute leukemia cells. Cancer Res. 2004;64:2580-9.

19. Waby JS, Chirakkal H, Yu C, Griffiths GJ, Benson $\mathrm{RS}$, Bingle $\mathrm{CD}$, et al. $\mathrm{Sp} 1$ acetylation is associated with loss of DNA binding at promoters associated with cell cycle arrest and cell death in a colon cell line. Mol Cancer. 2010;9:275.

20. Kobayashi N, Kunieda T, Sakaguchi M, Okitsu T, Totsugawa T, Maruyama M, et al. Active expression of p21 facilitates differentiation of immortalized human hepatocytes. Transplant Proc. 2003;35:433-4.

21. Merchant JL, Bai L, Okada M. ZBP-89 mediates butyrate regulation of gene expression. J Nutr. 2003;133(7 Suppl):2456S-60S.

22. Monneret C. Histone deacetylase inhibitors. Eur J Med Chem. 2005;40:1-13.

23. Prince HM, Bishton MJ, Harrison SJ. Clinical studies of histone deacetylase inhibitors. Clin Cancer Res. 2009;15:3958-69.

24. Cuff MA, Shirazi-Beechey SP. The importance of butyrate transport to the regulation of gene expression in the colonic epithelium. Biochem Soc Trans. 2004;32:1100-2.

25. Astbury SM, Corfe BM. Uptake and metabolism of the short-chain fatty acid butyrate, a critical review of the literature. Curr Drug Metab. 2012;13:815-21.

26. Li H, Myeroff L, Smiraglia D, Romero MF, Pretlow TP, Kasturi L, et al. SLC5A8, a sodium transporter, is a tumor suppressor gene silenced by methylation in human colon aberrant crypt foci and cancers. Proc Natl Acad Sci U S A. 2003;100:8412-7.
27. Paroder V, Spencer SR, Paroder M, Arango D, Schwartz S, Jr., Mariadason JM, et al. $\mathrm{Na}(+) /$ monocarboxylate transport (SMCT) protein expression correlates with survival in colon cancer: molecular characterization of SMCT. Proc Natl Acad Sci U S A. 2006;103:7270-5.

28. Thangaraju M, Gopal E, Martin PM, Ananth S, Smith SB, Prasad PD, et al. SLC5A8 triggers tumor cell apoptosis through pyruvate-dependent inhibition of histone deacetylases. Cancer Res. 2006;66:11560-4.

29. Heath JR, Davis ME. Nanotechnology and cancer. Annu Rev Med. 2008;59:251-65.

30. Pellizzaro C, Coradini D, Morel S, Ugazio E, Gasco MR, Daidone MG. Cholesteryl butyrate in solid lipid nanospheres as an alternative approach for butyric acid delivery. Anticancer Res. 1999;19:3921-5.

31. Gasco M.R. Solid lipidic nanospheres suitable to a fast internalization into cells. Patent WO 2000030620 A1. 2000

32. Ugazio E, Marengo E, Pellizzaro C, Coradini D, Peira E, Daidone MG, et al. The effect of formulation and concentration of cholesteryl butyrate solid lipid nanospheres (SLN) on NIH-H460 cell proliferation. Eur J Pharm Biopharm. 2001;52:197-202.

33. Brioschi A, Zenga F, Zara GP, Gasco MR, Ducati A, Mauro A. Solid lipid nanoparticles: could they help to improve the efficacy of pharmacologic treatments for brain tumors? Neurol Res. 2007;29:324-30.

34. Salomone B, Ponti R, Gasco MR, Ugazio E, Quaglino $\mathrm{P}$, Osella-Abate $\mathrm{S}$, et al. In vitro effects of cholesteryl butyrate solid lipid nanospheres as a butyric acid prodrug on melanoma cells: evaluation of antiproliferative activity and apoptosis induction. Clin Exp Metastasis. 2000;18:663-73.

35. Serpe L, Catalano MG, Cavalli R, Ugazio E, Bosco $\mathrm{O}$, Canaparo R, et al. Cytotoxicity of anticancer drugs incorporated in solid lipid nanoparticles on HT-29 colorectal cancer cell line. Eur J Pharm Biopharm. 2004;58:673-80.

36. Serpe L, Laurora S, Pizzimenti S, Ugazio E, Ponti R, Canaparo R, et al. Cholesteryl butyrate solid lipid nanoparticles as a butyric acid pro-drug: effects on cell proliferation, cell-cycle distribution and c-myc expression in human leukemic cells. Anticancer Drugs. 2004;15:525-36.

37. Brioschi A, Zara GP, Calderoni S, Gasco MR, Mauro A. Cholesterylbutyrate solid lipid nanoparticles as a butyric acid prodrug. Molecules. 2008;13:230-54.

38. Minelli R, Serpe L, Pettazzoni P, Minero V, Barrera G, Gigliotti C, et al. Cholesteryl butyrate solid lipid nanoparticles inhibit the adhesion and migration of colon cancer cells. Br J Pharmacol. 2012;166:587601.

39. Joshi MD, Muller RH. Lipid nanoparticles for parenteral delivery of actives. Eur J Pharm Biopharm. 2009;71:161-72. 
40. Souto EB, Muller RH. Lipid nanoparticles: effect on bioavailability and pharmacokinetic changes. Handb Exp Pharmacol. 2010;197:115-41.

41. Bruns T, Peter J, Hagel S, Herrmann A, Stallmach A. The augmented neutrophil respiratory burst in response to Escherichia coli is reduced in liver cirrhosis during infection. Clin Exp Immunol. 2011;164:346-56.

42. Bustin SA, Benes V, Garson JA, Hellemans J, Huggett J, Kubista M, et al. The MIQE guidelines: minimum information for publication of quantitative real-time PCR experiments. Clin Chem. 2009;55:611-22.

43. Mehnert W, Mader K. Solid lipid nanoparticles: production, characterization and applications. Adv Drug Deliv Rev. 2001;47:165-96.

44. Yuan H, Miao J, Du YZ, You J, Hu FQ, Zeng S. Cellular uptake of solid lipid nanoparticles and cytotoxicity of encapsulated paclitaxel in A549 cancer cells. Int J Pharm. 2008;348:137-45.

45. Martins S, Costa-Lima S, Carneiro T, Cordeiro-daSilva A, Souto EB, Ferreira DC. Solid lipid nanoparticles as intracellular drug transporters: an investigation of the uptake mechanism and pathway. Int J Pharm. 2012;430:216-27.

46. Chopin V, Toillon RA, Jouy N, Le Bourhis X. Sodium butyrate induces P53-independent, Fasmediated apoptosis in MCF-7 human breast cancer cells. Br J Pharmacol. 2002;135:79-86.

47. Joseph J, Mudduluru G, Antony S, Vashistha S, Ajitkumar P, Somasundaram K. Expression profiling of sodium butyrate $(\mathrm{NaB})$-treated cells: identification of regulation of genes related to cytokine signaling and cancer metastasis by $\mathrm{NaB}$. Oncogene. 2004;23:6304-15.

48. Sawa H, Murakami H, Ohshima $Y$, Sugino $T$, Nakajyo T, Kisanuki T, et al. Histone deacetylase inhibitors such as sodium butyrate and trichostatin A induce apoptosis through an increase of the bcl-2related protein Bad. Brain Tumor Pathol. 2001;18:109-14.
49. Chirakkal H, Leech SH, Brookes KE, Prais AL, Waby JS, Corfe BM. Upregulation of BAK by butyrate in the colon is associated with increased Sp3 binding. Oncogene. 2006;25:7192-200.

50. Fiskus W, Rao R, Fernandez P, Herger B, Yang Y, Chen J, et al. Molecular and biologic characterization and drug sensitivity of pan-histone deacetylase inhibitor-resistant acute myeloid leukemia cells. Blood. 2008;112:2896-905.

51. Siavoshian S, Blottiere HM, Cherbut C, Galmiche JP. Butyrate stimulates cyclin D and p21 and inhibits cyclin-dependent kinase 2 expression in HT-29 colonic epithelial cells. Biochem Biophys Res Commun. 1997;232:169-72.

52. Bandyopadhyay D, Mishra A, Medrano EE. Overexpression of histone deacetylase 1 confers resistance to sodium butyrate-mediated apoptosis in melanoma cells through a p53-mediated pathway. Cancer Res. 2004;64:7706-10.

53. Harms KL, Chen X. Histone deacetylase 2 modulates p53 transcriptional activities through regulation of p53-DNA binding activity. Cancer Res. 2007;67:3145-52.

54. Palani CD, Beck JF, Sonnemann J. Histone deacetylase inhibitors enhance the anticancer activity of nutlin-3 and induce p53 hyperacetylation and downregulation of MDM2 and MDM4 gene expression. Invest New Drugs. 2012;30:25-36.

55. Condorelli F, Gnemmi I, Vallario A, Genazzani AA, Canonico PL. Inhibitors of histone deacetylase (HDAC) restore the p53 pathway in neuroblastoma cells. Br J Pharmacol. 2008;153:657-68.

56. Archer SY, Meng S, Shei A, Hodin RA. p21(WAF1) is required for butyrate-mediated growth inhibition of human colon cancer cells. Proc Natl Acad Sci U S A. 1998;95:6791-6. 